\title{
Back to Schengen: the collective securitisation of the EU free-border area
}

\section{Michela Ceccorulli}

To cite this article: Michela Ceccorulli (2019) Back to Schengen: the collective securitisation of the EU free-border area, West European Politics, 42:2, 302-322, DOI: 10.1080/01402382.2018.1510196

To link to this article: https://doi.org/10.1080/01402382.2018.1510196

曲 Published online: 20 Nov 2018.

Submit your article to this journal $\pi$

Џ Article views: 1146

Q View related articles $\asymp$

View Crossmark data

4 Citing articles: 4 View citing articles 


\title{
Back to Schengen: the collective securitisation of the EU free-border area
}

\author{
Michela Ceccorulli
}

Department of Political and Social Science, University of Bologna, Italy

\begin{abstract}
This article considers how a major influx of migrants from North Africa and the Middle East during 2015 led to an EU-initiated collective securitisation of the Schengen space. The events of 2015 represented an internal crisis for the EU. This was not simply because migration stretched host country facilities and created political division within and between the member states. The uncoordinated reintroduction of border controls by some member states threatened the unravelling of the Schengen Agreement itself. The consequent security discourse which then gained currency in EU documents strongly underlined the need 'to go back to normality' and 'to go back to Schengen', not only to manage increasingly tense relations among member states but also to preserve what was seen as a core achievement of the EU. Contrary to the expectations of mainstream literature on securitisation, the policies enacted in response to the securitisation of Schengen have violated neither 'normal politics' of the EU nor existing or planned policies on migration and asylum despite the wide contestation of current EU migration and asylum practices. The article concludes that the normative dimension behind this collective securitisation should not be underestimated or too easily discounted.
\end{abstract}

KEYWORDS Migration; Schengen; securitisation; European Union; security governance

What in 2015-2016 became known as the European 'refugee' or 'migrant crisis' (BBC 2016) in fact embodied many discrete, cascading events, some of which had only a tangential or tenuous connection to the massive flow of persons en route to the European Union (EU). One by-product of this trajectory has been the progressive emergence within the EU of an 'internal emergency' that threatened the collapse of the Schengen Agreement, one of the EU's greatest achievements and critical to the realisation of a closer European Union. Ian Traynor claimed in January 2016 that the 'Schengen obituaries are being written', an impression largely shared and debated by many other actors, member states, think tanks and policy-makers (Traynor 2016). 
Rather than assessing the securitisation of the general phenomenon the refugee crisis and the unprecedented irregular inflows of migrants into the EU (Lazaridis and Wadia 2015) - this piece gives particular attention to an important component of that crisis, one that speaks directly to the EU as such. It focuses, in other words, on the collective securitisation of the Schengen regime and the ontological threat to the EU that this process represented.

The Schengen area was created by an agreement in 1985 among five members of the then European Economic Community (EEC). It was subsequently embedded in the EU's institutional architecture and came to encompass the vast majority of EU member states (with some notable exceptions such as the United Kingdom) plus non-members Norway, Iceland, Lichtenstein and Switzerland. The value of Schengen for the European integration project is self-evident to committed Europeanists: within the Schengen area there are no internal borders and the free movement of persons (EU citizens in primis) has been elevated to a fundamental right. The absence of internal border controls has yielded positive economic externalities (for instance, the absence of administrative delays at borders) and efficiency gains by enhancing the mobility of labour. Given its value, the Schengen agreement has acquired the status of a security referent for its members; it facilitates collective action to meet the goals of border security (however defined) and is sustained by common interests, both material (enhanced border control and minimal interference with the goals of the single market) and ideational (commonly held rules and norms contributing to the European integration project). Migration in 2015 threatened to unravel these various layers and so gave rise to a securitisation of Schengen as such, with efforts made to provide 'internal' order to otherwise uncoordinated patterns of member state action. As a consequence, the securitisation move had the effect of highlighting the priority the EU had accorded to EU internal security over and above the plight of the 'othered' migrants.

This argument is unpacked in four sections consistent with the general model provided by Sperling and Webber (2018). First, the 'normal' discourse and practice in relation to Schengen prior to 2015 is presented, complemented by an overview of the parallel security discourse found in the 2015 Agenda on Migration (European Commission 2015a); this policy document links the migration phenomenon to the EU's internal dynamics. The second section provides a description of the multiple and parallel 'precipitating events' which led the EU to assume the role of security principal and to initiate the process of securitising Schengen. The third section considers the EU's emergence as an agent of securitisation more explicitly. The securitising move, and its reception by the member states 
as audience are, in turn, considered as indicative of the recursive interaction that facilitates collective securitisation. Section four then describes the policy response - the EU's attempt to preserve Schengen and mitigate the threat posed to the internal cohesion of the Union. In the conclusion, I return to the peculiarities of this collective securitisation effort, the security governance logic that has followed from it, and the possible normative dilemmas posed by the securitisation move and its policy consequences.

\section{Schengen and security}

The establishment and functioning of Schengen in the 1990s inevitably required that the EU perform as a security actor (Kirchner and Sperling 2007: 163-4) because, according to the European Commission (2018a), 'the abolition of internal border controls cannot come at the expenses of security'. The effective removal of internal controls has only been possible through the tightening of the common external border. This has compelled Schengen frontier states to assume the responsibility for controlling the EU's common external border 'on behalf of the other Schengen states' (European Commission 2018b). Yet the European Commission (2011: 6) has realised equally that safeguarding the freedom of movement ought not to compromise a member state's ability to deal with serious threats to public policy or security. Consequently, in order to ensure the acceptance and functioning of Schengen, provisions were made that allowed member states the ability, in exceptional circumstances, to reintroduce border controls when a threat to public policy or internal security arose. But the temporary suspension of Schengen was subject to two conditions: such controls would be limited in duration; and other Schengen countries, the European Parliament and the Commission would receive prior notification.

If a frontier member state were to exhibit persistent and serious deficiencies in the carrying out of external border control (evaluated through a set of criteria verifying the application of the Schengen acquis) that 'put the overall functioning of the area without internal border control at risk' and so presented a serious threat to public policy or internal security, then other member states could reintroduce border controls upon a proposal of the Commission and a recommendation of the Council so as to 'protect the common interests within the area without internal border control' (European Parliament and European Council 2006). The option of suspending Schengen, however, was viewed as a last resort of limited duration. It was also recognised that, independently of a member state's ability to exert effective control of the external border, the crossing of the 
external border by an uncontrollable influx of third-country migrants could cause 'unexpected and significant' secondary movements of irregular immigrants that may constitute a serious threat for the Union or some member states. In this circumstance, the reintroduction of internal border controls, though as a last resort, would be a feasible policy option (European Commission 2011: 11). Hence, it was understood by the EU and member states alike that massive and unregulated migration could produce internal disruptions directly or indirectly via the heightened possibility of secondary movements in a border-free space.

Before 2015, the recorded violations of the Schengen acquis on controls at internal borders were negligible. Member states only reintroduced controls on a few occasions and did so in conformity with the legal framework and normative expectations of the Schengen regime (European Commission 2013). The Commission constantly emphasised the necessity of coordinating EU policy responses designed to safeguard the right of free movement, while limiting the possibility of unilateral national initiatives that could 'never be an effective response to common threats' (European Commission 2011: 3). The Commission also underscored that the Community method should prevail when devising and coordinating the exceptional and temporary reintroduction of internal border controls:

Since the free movement of persons within the area without internal borders is a key Union achievement, the benefits of which are enjoyed by all the persons living in this area ... it should as a general rule require a decision to be taken at the Union level, rather than for such decision to be taken unilaterally at the national level. (European Commission 2011: 5)

Hence, the normal functioning of Schengen was understood by the EU as 'maintaining the absence of border controls' (European Commission 2013), thanks both to strengthened measures at the external border and a set of measures codified at the EU level allowing for the temporary and coordinated (i.e. among member states and EU institutions) reintroduction of border controls as a last resort. Both features testified to the EU's desire to safeguard the Schengen area, but equally demanded that member states significantly contribute to this effort, giving substance to the 'mutual trust' at the heart of the Schengen contract (European Commission 2011). Even in the case of a massive influx of migrants, Schengen could be maintained through the strict application of its working provisions. However, such assumptions would prove extremely fragile when tested against the reality of uncontrolled migration from war-torn areas of the world.

The EU was fully aware that the number of migrants and asylum seekers soared between 2015 and 2016 and understood the difficulty of easily or rapidly managing the influx. In fact, the Agenda on Migration 
(European Commission 2015a), issued in May 2015, contained both short- and long-term measures to tackle the massive inflows of migrants and asylum seekers into Europe and to set the basis for a more farsighted handling of the issue (Ceccorulli and Lucarelli 2018). Concurrent with short-term initiatives taken to help manage the immediate concern with controlling migrant inflows, the EU considered other medium- and long-term measures that would help avoid similar disruptions in the future. The policy goals here were to prevent uncontrolled migration at its source and to enhance the EU's ability to cope with it. But the Union's (and member states') primary focus on the 'external' challenge represented by the arrival of massive numbers of asylum seekers (tellingly mis-specified as a 'refugee crisis') had the effect of deflecting the real crisis: an imminent 'internal' emergency that would soon impact the viability of the Schengen system itself. The progressive acknowledgement of this emerging challenge was revealed in the multi-phased implementation packages of the Agenda on Migration, which expressed a significant change in the EU's perception of security in this regard. But what exactly were the components of this policy shift and redefinition of security?

\section{Precipitating event(s): not one, not mainly external, not a shock}

EU measures to mitigate the refugee crisis mirrored two security discourses set forth in the Agenda on Migration with respect to migration management: preventing the loss of migrants' lives and securing EU borders (see also European Commission 2015b). Gradually, the concern with the latter took precedence. This shift was evident in member state disregard of some of the recommended measures contained in two implementation packages and by events that unfolded in parallel with those measures.

In May 2015, the Union issued the first 'implementation package' of the Agenda on Migration aimed at relieving the migratory pressures on frontline states. At that point, attention was mainly directed at enforcing a relocation plan among member states and at preventing migrant deaths at sea. In response to Italian and Greek entreaties, the European Commission proposed, on the basis of Article 78(3) TFEU (never yet triggered), a temporary relocation scheme among the member states. That programme was geared toward alleviating pressure on reception capabilities in Greece and Italy and avoiding uncontrolled secondary movements to interior states (European Commission 2015c). The emphasis, hence, was on showing solidarity with states at the frontier; the Council was urged to approve the Decision and member states to implement it. The Commission committed itself to support Italy and Greece operationally 
and financially and requested that both member states improve their own asylum systems and repatriation capacities. The Commission reasoned that since the migration and asylum crisis constituted a common challenge, the EU had to collectively provide a way out of the emergency (European Commission 2015c: 8). A total of 40,000 migrants (24,000 in Italy and 16,000 in Greece), classified as persons 'in clear need of international protection', were to be relocated in other member states. In September 2015, the Council adopted the European Commission Decision (European Council 2015a) outlining provisional measures supporting Italy and Greece amid member state haggling over the number of persons to be relocated and the parameters for redistributing them equitably.

Prior to that Decision, however, two developments complicated EU action: first, the inflow of migrants increased over the summer of 2015; and second, the migratory pattern shifted and added Hungary as a new key transit route into the Schengen area. The eastern Mediterranean route rapidly became a favoured entry point, especially for Syrians. Relatedly, a significant portion of irregular entries into the EU occurred via the western Balkans. In response, the EU issued a 'Second Implementation Package' in September 2015. Relocation still figured prominently as a collective response, and the redistribution scheme was extended to Hungary. Migrants used Hungary primarily as a transit point to enter either Austria or Germany. As in the case of Italy and Greece, overwhelming flows coupled with deficiencies in Hungarian reception capacities facilitated secondary movements to other member states. A total of 120,000 persons in clear need of international protection (15,600 in Italy, 50,400 in Greece and 54,000 in Hungary) were to be relocated. The European Commission ensured direct support to the three states and committed to close oversight of member states' (mandatory) implementation of the scheme. The second relocation scheme Decision was approved on 23 September 2015, although Hungary, one of the presumed beneficiaries of that Decision, never committed to implementing the plan.

The perceived 'security' situation, then, was progressively changing. To the policy rhetoric emphasising the 'external' challenge posed by the massive influx of migrants, the EU added another layer of rhetoric that underscored the emergent internal challenge to the Schengen regime. The key manifestations of this internal challenge included the perception that Greece was incapable of controlling its external border and managing massive inflows of migrants and asylum seekers as well as the decision of some member states, partly as a reaction to the Greek failure, to reintroduce temporary internal border controls. The Second Implementation Package thus scaled down the 'saving of lives' discourse and encouraged a narrative dedicated to the preservation of Schengen. 
Uncontrolled migratory inflows indeed tested the EU (European Commission 2015d), revealing an unwillingness among the member states to coordinate actions. Relocation proceeded (if at all) at a very slow pace. The Commission, concerned at this state of affairs, pointed out that legislative (Regulations and Directives), financial (funding programmes under migration and internal security, but also funds relocated from other areas), and operational (European Asylum Support Office [EASO], the European Agency for the Management of Operational Cooperation at the External Borders [FRONTEX], the European Union Agency for Law Enforcement Cooperation [EUROPOL]) and crisis management mechanisms (Rapid Border Investigation Teams, Civil Protection Mechanism) were already at the member states' disposal to meet the exceptional challenge. The Commission charitably concluded that member state nonconformity with $\mathrm{EU}$ rules reflected an underappreciation of the range of policy instruments that were available (European Commission 2015d: 6). But despite the Commission's repeated attempts to promote a coordinated response (even threatening the possibility of sanctioning measures such as infringements procedures), the member states increasingly opted for the temporary introduction of national border controls so as to avoid secondary movements from frontier states.

Accordingly, the 'normalization of the Schengen area and the lifting of temporary internal border controls' started to become the Commission's key priority (European Commission 2015d: 7). Ever more attention was paid to Greece's inability to control its external border, a failure considered to be a major contributing factor to the rising pressure on the European asylum system. The Commission pointedly noted that it is a strong external border which allows us to free up our internal borders through the Schengen area, and to guarantee free movement of people' (European Commission 2015d: 13). Dublin Regulation transfers to Greece had been suspended since 2011 given the deficiencies in the Greek asylum system, while a soaring number of migrants intentionally entered the country in order to reach other preferred European destinations. Hence, Greece had to improve swiftly the robustness of its overall asylum system and thereby eliminate one of the most important incentives for secondary movement to other EU countries. The need to strengthen the external border at its weakest point also compelled consideration that a European Border and Coast Guard was necessary. Bringing back 'order' in migration management started to become a catchword, as did the so-called 'hotspot approach' for the identification, fingerprinting and registration of migrants upon arrival. The European Union intent in supporting this new approach was evident through the actions of relevant EU agencies (FRONTEX, EASO, EUROPOL and the European Union Judicial 
Cooperation Unit [EUROJUST]). Through such systems, relocation could be accelerated, the Dublin Regulation properly implemented, and the return of irregular migrants facilitated.

The rapidly worsening situation in the following months was reflected in the Commission's documents urging member states to implement fully and immediately already agreed upon provisions (European Commission 2015e). Since the proper management of the eastern Mediterranean route proved increasingly crucial to staunching the inflow of migrants, the EU invited Western Balkan states to agree upon a coordinated approach (European Commission 2015i). Coordination with Turkey was also envisaged and an EU-Turkey Action Plan was signed on 15 October 2015 (European Commission 2015f), followed by a Joint Statement in March 2016. The Commission, meanwhile, was finalising an opinion on the prolongation of temporary Austrian, German and Slovenian border controls. That action acknowledged the increasing 'internal' salience that the migration issue was acquiring. The November 2015 terrorist attacks in Paris only strengthened the emphasis on securing both external and internal borders.

When the Commission put forward the Third Implementation Package (or 'Border Package') in December 2015, it stated that the proposed measures would 'manage the EU's external borders and protect our Schengen area without internal borders' (European Commission 2015g). The road towards the collective securitisation of Schengen had been opened. The key provision of this package was the creation of the European Border and Coast Guard. In response to the 'exceptionally high' winter migratory inflows into the EU, especially into Greece, it became much more urgent that the EU and the member states accelerate the implementation of the hotspot system and the relocation scheme so as to alleviate the burden on frontier states, facilitate the return of irregular migrants, and improve national reception capacities (European Commission 2015h). Meanwhile, many member states, particularly Hungary, expressed discontent with Greece and identified it as the weakest link of the Schengen chain (Zalan 2015). The EU, in an effort to diffuse this mounting resentment, provided operational and financial support to help Greece manage the crisis, almost to the point of guiding and controlling the situation on the ground (European Commission 2015h). At the same time, given the huge increase in asylum applications, Sweden requested and obtained a derogation on its obligations under the relocation scheme (as did Austria in February 2016). By December 2015, Germany, Austria, Slovenia, Hungary, Sweden and non-EU Norway had reintroduced temporary controls at internal borders. France had already done the same in response to the terrorist attacks of November 2015. 
In the context of an ever disordered internal border security regime, multiple proposals arose on the future of Schengen (including one for a 'Mini-Schengen'). Public debate, meanwhile, articulated a notion of an EU in 'internal crisis' and, in parallel, questioned the very existence of the Schengen area (Brunsden et al. 2016; Guild et al. 2015; Peers 2015; Traynor 2016). Opinion polls showed member states and their citizens increasingly anxious and inclined toward the renationalisation of border controls (Diamanti 2016). At the beginning of 2016, tensions between Austria and Greece rose to such a pitch that the Commissioner for Migration bluntly warned that the system might 'break down' should such divisions spread to other countries or become more acute (Barigazzi 2016). The Austrian Minister for the Interior suggested it was necessary to move the Schengen frontier to central Europe since Greece was unable to 'secure' the Greek-Turkish border (Nielsen and Zalan 2016). Austria convened a mini-summit of the Balkan states in late February 2016, to which the Greeks were not invited. That summit produced the Vienna Declaration 'Managing Migration Together'. Preoccupied with limiting migratory flows through the Western Balkans route, it called on Schengen frontier states (i.e. Greece) to fulfil their obligations.

This downward spiral of increasingly strained relations threatened the survival of the Schengen area and led ultimately to the collective securitisation of Schengen. That securitisation, in turn, offers two important points for theoretical reflection, which support some arguments advanced in the introductory chapter of this special issue. First, migration in 2015 was a cumulative crisis - a cascading of events which challenged the security of the EU. Second, the problem, while externally generated (the upsurge in migration was an exogenous shock), had consequences for the endogenous character of the EU as a security provider.

The securitisation of Schengen does not provide an easy fit with the dichotomous categories of politicisation and securitisation; in this regard, it supports the thesis that 'politics does not evaporate at the doorstep of securitization' (Balzacq 2015). Rather, security is in a continuous and performative dialogue with politics, affecting and being affected by it. In the case under consideration, securitisation came as a process of overlapping rather than distinct, separate steps (Sperling and Webber 2018), while the tipping point can be traced to the member states' challenge to the passport-free zone. One may be tempted to give priority to one event over another, but to do so would risk marginalising or discounting equally important events. Likewise, the precipitating event may be considered the massive and sudden inflow of migrants, but this inflow, per se, did not push the Commission to securitise Schengen. The reintroduction of national border controls within the Schengen area was the single most 
threatening move against the preservation of the Schengen regime. The member states consciously chose the uncoordinated reintroduction of national border controls as the policy response rather than a common policy to alleviate the burden on the most affected states at the common EU frontier. And this conscious choice brought about the 'internal crisis' threatening the functioning and survival of the Schengen system. The restoration of the order and predictability afforded by the Schengen regime became the EU's utmost priority. Towards preventing a mass defection from Schengen, the Commission reminded the member states that 'the Schengen system contains a great deal of flexibility to allow member states to respond to evolving circumstance' (European Commission 2016a: 13). Keeping faith with the requirements of Schengen was essential if the EU were to avoid the costs attending its collapse.

\section{Schengen in crisis: the process of recursive interaction}

The member states' reluctance to abide by their commitments, the structural weaknesses in the border control and asylum systems of frontier states, multiple voices anticipating the death of Schengen and, above all, the uncoordinated reintroductions of national border controls within the EU opened the way for a securitisation move. And this move was much more than simply a mediation effort by the EU: it underscored the criticality of preserving Schengen and safeguarding the ontological security of the EU itself. As such, securitisation sought to unwind the unilateral imposition of national border controls and, relatedly, to restore order and predictability in view of the member states' uncoordinated actions. We can identify the relevant phases of the securitisation move and explore the constitutive moments of recursive interaction, whereby the authoritative security actor (those speaking on behalf of the EU, with the Commission and the Council taking the lead) interacts with the relevant empowering audience (the member states) to securitise a threat and agree upon necessary mitigating actions.

In an attempt to investigate the 'lesson learned' from the temporary reintroduction of controls at internal borders, the Luxembourg Council Presidency in late 2015 asked the member states to respond to a questionnaire. The results of that exercise underlined that many of the reintroduced internal border controls had occurred without prior notice, thereby negatively affecting bordering states' ability to adjust. At the same time, though, emphasis was placed on the potential challenges created by secondary movements, especially on asylum capabilities (European Council 2015b). Slovenia's Prime Minister Miro Cerar, for one, warned that if stricter controls were adopted by Germany and Austria, Slovenia could 
not but adopt the same policy; he explained that, notwithstanding his support for Schengen, he was responsible for ensuring the security of his own country from unwanted migration (Nielsen 2016). The Austrian Chancellor Werner Faymann similarly affirmed that the inability of the frontier member states to secure external borders both threatened the integrity of Schengen and compelled national leaders to reintroduce controls at their own national borders so as to preserve domestic tranquillity (Corriere della Sera 2016). The Presidency made clear, however, that there ought to be no allowance for the unilateral imposition of controls on internal borders for more than six months. It did acknowledge that the Schengen Border Code allowed, upon a proposal of the Commission, an extension of border controls for up to two years in response to cases of persistent border control deficiencies in frontier member states (European Council 2015b). The EU was nonetheless sending a message both to Greece (urging the full implementation of the EU's guidelines) and to the member states that unilateral action was impermissible.

In this context of persistent and uncontrollable migratory inflows and reinstituted national border controls, the EU's main institutional actors (the Council, the Commission and the Parliament) undertook a securitisation of Schengen. The Council Conclusions of 18-19 February 2016 stated:

[i]n response to the migration crisis facing the $\mathrm{EU}$, the objective must be to rapidly stem the flows, protect our external borders, reduce illegal migration and safeguard the integrity of the Schengen area. It is important to restore, in a concerted manner, the normal functioning of the Schengen area, with full support for member states which face difficult circumstances. (European Council 2016)

In that spirit, the European Council President Donald Tusk warned that '[s]aving Schengen is a race against time' (Holehouse 2015).

But it was the Commission that identified most emphatically the threat to Schengen and the broader implications for the Union. Its Communication of March 2016, tellingly titled 'Back to Schengen - A Roadmap', positioned Schengen as 'one of the major achievements of European integration ... one of the key means through which European citizens can exercise their freedoms, and the internal market can prosper and develop' (European Commission 2016b: 2). The spiral of events leading to the temporary reintroduction of borders by some member states had, the Communication continued, placed in question 'the proper functioning of the Schengen area of free movement'; its demise 'would risk destroying one of the central achievements of European integration and the construction of a shared European space' (European Commission 2016b: 2, 4). The Commission characterised the threat to Schengen as an 
internal crisis that exposed the shortcomings of the integration process in the migration and asylum domain. The desire to save Schengen thus required the $\mathrm{EU}$ to reconcile the reintroduction of internal border controls with existing legal frameworks governing Schengen. The Commission claimed that the Union had 'a clear roadmap to return to a normal functioning of the Schengen zone by November and we need to get there in an orderly way. We preserve Schengen by applying Schengen' (European Commission 2016b). This reconciliation process could only come into being after the Commission had 'formally' recognised the risk to the integrity of the Schengen space. In fact, it was only upon the Commission's recommendation that the Council could eventually trigger the safeguard procedure of Article 29 of the Schengen Border Code.

The costs of, and implications for, the demise of Schengen were also made clear in studies of the European Parliament. Internal border controls, these argued, could disrupt the operation of the Single Market and 'endanger the future benefits of ... EU integration' (European Parliament 2016a: 1; see also European Parliament 2016b, 2016c). This was a view echoed even by those states that had themselves reintroduced border controls; such measures being regarded as inevitable rather than as intrinsically desirable. Hungary, especially critical of the EU's handling of the refugee crisis, nonetheless urged Brussels 'to preserve the passport free area at all costs' (Kahn 2016), a position echoed in the sentiments of leaders in Poland and other east European member states (Potyrała 2016).

Summing up, the securitisation of Schengen was the climax of a series of developments both internal and external to the EU. The stakes were particularly high for the EU, and this is why the process went far beyond the mediation of member state positions: the survival of Schengen was given priority over any other issue and that became a key aim of the EU's agenda, shared by the Commission, the Council and the Parliament and accepted by the most relevant empowering audience, the member states. In this security discourse, the 'saving the lives' objective was clearly sidelined by that of the 'security of borders'.

\section{Normalising the Schengen area: EU security governance}

The collective securitisation of the Schengen area had significant implications for the European system of security governance as well as for the interaction density among the member states. A first observation here is that the securitisation move did not produce emergency responses that violated the Union method of internal governance. On the contrary, the initial securitisation reflected the EU's role as system regulator and an attempt to reconcile the uncoordinated moves of the member states with 
established EU crisis management tools, especially the Schengen Borders Code. Also, most of the measures taken to minimise the threat to Schengen were in the legislative pipeline before the 'internal' crisis erupted. If anything, the securitisation of Schengen enabled the EU to gain the upper hand vis-à-vis the member states and so enforce the accelerated implementation of planned measures. Second, the securitisation process reconciled short-term objectives (to keep Schengen alive and mitigate the immediate security concerns of the member states) with long-term objectives (reducing the overall number of migrants en route to the EU and strengthening measures of crisis management), hence reinforcing the EU's security actorness in this policy domain.

The security governance provisions to bring Schengen to normality can be found in the Commission's 'Back to Schengen' document (subsequently endorsed in a Statement by EU Heads of State and Government on 7 March 2016). Both documents attempted to define appropriate behaviour for member states (regulatory interaction, in other words) and to leverage member state security needs into institutionalised behaviour (patterned interaction). 'Back to Schengen' gave priority to three sets of demands. First, the lack of control by Greece over its external border had to be addressed; the country had to become compliant with Schengen requirements and the EU's asylum legislation more generally. Second, member states had to end the 'wave-through' approach by fully implementing existing EU law and recent decisions on asylum. And third, a coordinated framework was required in order to lend coherence to the 'patchwork of unilateral decisions' on internal borders taken by eight countries in the Schengen area (European Commission 2016b). Concurrently, the Parliament and Council were asked to swiftly adopt the Regulation establishing the European Border and Coast Guard proposal in conjunction with efforts to significantly reduce irregular inflows towards the EU in partnership with Turkey. Aside from ensuring coordinated member state actions with respect to internal border controls, none of the other measures proposed was new or violated 'normal' policy processes within the EU.

The introduction of temporary border controls by some member states was, in fact, the single most apparent threat to the Schengen system. Member state responses to the influx of migrants spanned a range of national securitisation moves taken in an uncoordinated fashion and without regard to their impact on other member states (European Commission 2016c). The EU's action in response was geared not to eliminating border checks but rendering them compatible with the EU's normative-legal framework. The Commission acknowledged the inability of Greece to control the common external border and that unregistered 
migrants stranded in Greece could move irregularly to other member states. Consequently, in May 2016 it recommended the activation of Article 29 of the Schengen Borders Code (European Commission 2016c: 7). The Council followed up shortly after with an implementing decision. The proposal was intended to mitigate 'serious threats to public policy or internal security within the Schengen area' and 'to address the threat putting at risk the overall functioning of the area without internal border controls' (European Commission 2016c: 8). The recommendation did not exclude Greece from Schengen, as some member states had proposed, but 'allowed and institutionalised' the prolongation of existing controls at internal borders (of Austria, Denmark, Germany, Sweden and Norway).

Aside from this specific provision, the measures proposed in the Back to Schengen Roadmap had already been advanced in the 2015 Agenda on Migration, and hence before the 'internal crisis' erupted. Greece had been under close scrutiny by the EU since inflows started to shift towards the eastern Mediterranean route. Other measures advanced in the Roadmap, such as the effective implementation of the hotspot system, new guidance for fingerprint collection into the European Dactyloscopie (EURODAC) (extended also to irregular migrants on top of asylum seekers), the proposal to shift existent Directives on asylum into Regulations and enhanced coordination with the Western Balkan states were already planned or primed for implementation. This package of measures was seen as a means of compensating for the 'wave-through' approach of some member states and of reducing secondary movements of migrants that threatened to create intolerable imbalances among member states. Ultimately, the positive effects of reduced secondary movements would pave the way for the effective implementation of orderly relocation and resettlements plans. Efforts to adapt existing systems (such as the Dublin Regulation allocating responsibility for the examination of asylum requests) for prospective migration crises gained momentum, but as these were already in gestation they cannot be seen as a direct product of the securitisation move (European Commission 2016d).

But the securitisation move did have an accelerating effect on pending measures. Repeated failures to create the European Border and Coast Guard (in 2001, 2004, 2006 and 2014) were finally overcome. EU dialogue with Turkey was also taken forward. A Visa Liberalisation Dialogue with Turkey had been launched in 2013 leading to discussions on the possibility of visa-free short-stay entries in the EU for Turkish citizens; an EUTurkey readmission agreement then entered into force in 2014. Together with the Joint Action Plan signed in October 2015, this measure provided the EU with a voice on Turkey's migration policy, with a view to 
stemming irregular immigration through the readmission of third country nationals (European Commission 2016e). A Greek-Turkish readmission protocol, in force since 2001, was also significantly strengthened, as was cooperation in the last months of 2015, thanks in part to the NATO naval deployment in the Aegean Sea. These moves culminated in the 18 March Statement between the EU and Turkey. The deal (practically sealing the EU's eastern border) was harsher than previous cooperation provisions with Turkey. In the Communication that preceded the Statement, the Commission underlined that 'whilst some important steps are still needed, the means, both legal and practical, exist to initiate the new arrangements as a matter of urgency' (European Commission 2016f).

The overlap of measures to save Schengen with those directed at coping with the 'refugee crisis' (producing a sort of continuity in the system of security governance) leads to a second observation. The main rationale behind this augmented system of border governance was that massive inflows were likely to create insecurity within and possible tensions among member states. If such tensions constituted a challenge to the EU as such, then preventing arrivals on the EU's territory seemed the most reasonable solution to forestall such an outcome. The European Border and Coast Guard has been generally interpreted as a qualitative improvement of the EU agency FRONTEX for the control of the external border and the prevention of future crises. In this vein, the agreement with Turkey should be viewed as a possible model for strengthening relations with third countries. ${ }^{1}$

\section{Conclusion}

The massive and uncontrolled number of migrants and asylum seekers arriving in Europe between 2015 and 2016 is commonly referred to as the EU 'refugee crisis'. This inflow constituted a concomitant 'internal crisis' that posed a threat to EU's ontological security: that is, a threat 'to the very basis of the [EU's] collective self (Ceccorulli and Lucarelli 2018). The collective securitisation of Schengen has been the product of such an acknowledgment. The security threat - and response - took the form of a collective effort by the EU to meet an existential challenge to a core achievement of the EU. The internal debate within the EU and the policy responses flowing from it reveal that that the underlying policy preoccupation was preserving the Schengen regime. The securitisation of Schengen answered an internal, rather than an external crisis. The EU had as its declared objectives the restoration of the normal functioning of Schengen - indeed, the preservation of the Schengen area as such. Hence, 
the securitisation of Schengen stands as a particularly 'political' act in the choice of securitisation (Waever 2015).

This process of collective securitisation was not an answer to a single event; rather, the analysis has shown that it was a product of both sequential and parallel interactions, ranging from the Greek inability to control the external border to the temporary reintroduction of internal border controls by some member states. This latter move, in particular, demonstrated the magnitude of the internal crisis; the uncoordinated imposition of internal border controls posed the clearest existential threat to the Schengen area. In addition, the triggering events were not or not only 'external' to the EU, but largely internal in origin: 'wave-through' practices, implementation failures and unilateral moves. The securitisation of Schengen retained an emphasis on securing borders, but more as a means of ensuring good EU governance - the necessity of actions to 'save lives' was subsequently marginalised.

Yet the securitisation move did not ignite a radically 'new' form of security governance. Alongside realigning member states' unilateral moves to the normative and legal framework embedded in the Schengen Borders Code, the Roadmap proposed to re-establish Schengen via the full implementation of already agreed-upon policies. Nonetheless, in some cases the securitisation of Schengen did allow the EU to fast track provisions, evident in initiatives taken with Turkey and the rolling out of the European Border and Coast Guard. In this sense, measures intended to preserve the Schengen area coincided with both short-term responses to the refugee crisis as well as to longer-term strategy for handling migration in years to come. Combined, this meant security achieved a new prominence in the EU's approach to the handling of migration and asylum.

Finally, the normative dimension of the securitisation move cannot be overlooked (see also Floyd 2018). The normative issue is all the more pertinent given that the collective effort by the EU went far beyond mediating the member states' divergent positions. Overall, the theoretical toolkit on the ethics of migration provide contrasting positions on how the EU's actions should be judged (Gibney 2004; Macdonald 2015). For all their ethical force, 'partialism' (giving priority to the claims of the internal community) and 'impartialism' (weighing impartially the claims of the members of the community and of outsiders) could not be easily reconciled in this case. If, as suggested by Gibney (2004), both particular and universal claims have to be taken into account for a normative approach to be politically relevant, how might this translate into a purposefully normative policy response when the actor under scrutiny is the EU? Representing a core value for the $\mathrm{EU}$ and one of the key accomplishments of its integration process, the securitisation and then the 
normalisation of Schengen may be interpreted in itself as a morally legitimate move, underscoring the collective responsibility of the EU as a security actor. However, the EU in formulating a policy response has had to take into account three competing claims: those of its member states (one version of partialism); those relating to universal human rights (impartialism); and those that relate to the EU's existence as an authoritative security actor principally expressed in the integrity of the Schengen space (a second version of partialism). Put slightly differently, any evaluation of the ethical dimension of collective securitisation must take into account the closeness of fit between the preservation of security governance and the broader normative claims of the relevant security actor (the EU in this case). The securitisation of the Schengen space can be tentatively assessed as a move with ethical power in itself. Yet its consequences, in terms of governance, resulted in the prioritisation of the security of internal space over the claims of migrants and asylum seekers. That choice raises the equally compelling question: can the EU act as a normative power when its ontological security is under threat? This case suggests that it cannot.

\section{Acknowledgements}

I wish to thank Jim Sperling, Sonia Lucarelli, Mark Webber, Christian Kaunert and all other participants to this Special Issue for valuable suggestions/comments on an earlier version of this work. My gratitude also goes to Spyros Economides and the three anonymous Reviewers of my article.

\section{Disclosure statement}

No potential conflict of interest was reported by the author.

\section{Funding}

This article draws on research conducted in the context of the project GLOBUS Reconsidering European Contributions to Global Justice, which received funding from the European Union's Horizon 2020 research and innovation programme under grant agreement no. 693609. For more information: http://www.globus.uio.no.

\section{Notes on contributor}

Michela Ceccorulli is Research Fellow and Adjunct Professor at the University of Bologna. She is also Adjunct Professor at the Dickinson Center for European Studies (Dickinson College, Carlisle, PA) in Bologna. She is currently involved in a Horizon 2020 Project - GLOBUS - Reconsidering European Contributions to Global Justice. She is the co-editor (with Nicola Labanca) of The EU, Migration and the Politics of Administrative Detention (Routledge, 2014). Her work on 
security governance and migration has been published in European Security, the International Spectator, Global Affairs, Contemporary Politics and Mediterranean Politics.

\section{Note}

1. This kind of policy initiative is central to the Agenda on Migration and the new EU Global Strategy, both of which emphasise the role of the 'external dimension' to migration (European Commission 2016g).

\section{References}

Balzacq, Thierry (2015). 'The "Essence" of Securitization: Theory, Idealtype, and a Sociological Science of Security', International Relations, 29:1, 103-13.

Barigazzi, Jacopo (2016). 'EU Migration System “Could Break Down” in 10 Days', Politico, 25 February, available at: http://www.politico.eu/article/eu-migrationsystem-could-collapse-in-10-days-refugees-political-tension/ (accessed 20 June 2018).

BBC (2016). 'Migrant Crisis: Migration to Europe Explained in Seven Charts' (4 March 2016), available at: https://www.bbc.co.uk/news/world-europe34131911 (accessed 20 June 2018).

Brunsden, Jim, Hope Kerin and Spiegel Peter (2016). 'EU Threatens to Reimpose Greek Border Controls', Financial Times, 27 January, available at: https://www. ft.com/content/674647a6-c4f9-11e5-808f-8231cd71622e (accessed 17 September 2018).

Ceccorulli, Michela and Sonia Lucarelli (2018). 'Migration', in James Sperling and Spyros Economides (eds.), The EU's Security Strategies. Abingdon, Oxon and New York: Routledge.

Corriere della Sera (2016). 'Migranti, l'annuncio del Cancelliere: l'Austria vuole sospendere Schengen', 16 January, available at: http://www.corriere.it/esteri/16_ gennaio_16/migranti-l-annuncio-cancelliere-l-austria-sospende-schengen-2a99c9 fc-bc8b-11e5-b206-2a6e9b3d9bfb.shtml (accessed 20 June 2018).

Diamanti, I. (2016). 'L'Europa si chiude, cresce la voglia di confini: solo i giovani dicono no', Repubblica, 9 May, available at: http://www.repubblica.it/politica/ 2016/05/09/news/osservatorio_europeo_1_italia_e_il_paese_piu_vecchio_d_el_ continente_nel_2015_la_popolazione_e_scesa_di_100mila_unit-139395184/ (accessed 20 June 2018).

European Commission (2011). Schengen Governance-Strengthening the Area without Internal Border Control. Brussels, COM (2011) 561 final, 16 September.

European Commission (2013). Third Biannual Report on the Functioning of the Schengen Area. 1 November 2012-30 April 2013. Brussels, COM(2013) 326 final, 31 May.

European Commission (2015a). A European Agenda on Migration. Brussels, $\operatorname{COM}(2015) 240$ final, 13 May.

European Commission (2015b). The European Agenda on Security. Brussels, $\operatorname{COM}(2015) 185$ final, 28 April. 
European Commission (2015c). Proposal for a Council Decision on Establishing Provisional Measures in the Area of International Protection for the Benefit of Italy and Greece. Brussels, COM(2015) 286 final, 27 May.

European Commission (2015d). Managing the Refugee Crisis: Immediate Operational, Budgetary and Legal Measures, under the European Agenda on Migration. Brussels, COM (2015) 490 final/2, 29 September.

European Commission (2015e). Managing the Refugee Crisis: State of Play of the Implementation of the Priority Actions, under the European Agenda on Migration. Brussels, COM (2015) 510 final, 14 October.

European Commission (2015f). EU-Turkey Joint Action Plan. Fact Sheet, 15 October.

European Commission (2015g). A European Border and Coast Guard to protect Europe's External Borders. Press Release, 15 December.

European Commission (2015h). Progress Report on the Implementation of the hotspots in Greece. Brussels, COM (2015) 678 final, 15 December.

European Commission (2015i). 'Meeting on the Western Balkans Migration Route: Leaders Agreeon 17-point Plan of Action' (Press Release, 25 October), available at: http://europa.eu/rapid/press-release_IP-15-5904_en.htm (accessed 20 June 2018).

European Commission (2016a). Communication on the State of Play of Implementation of the Priority Actions under the European Agenda on Migration. Brussels, COM (2016) 85 final, 10 February.

European Commission (2016b). Back to Schengen-A Roadmap. Brussels, COM (2016) 120 final, 4 March.

European Commission (2016c). Proposal for a Council Implementing Decision Setting out a Recommendation for Temporary Internal Border Control in Exceptional Circumstances Putting the Overall Functioning of the Schengen Area at Risk. Brussels, COM (2016) 275 final, 4 May.

European Commission (2016d). Towards a Reform of the Common European Asylum System and Enhancing Legal Avenues to Europe. Brussels, COM (2016) 197 final, 6 April.

European Commission (2016e). EU-Turkey Joint Action Plan - Third Implementation Report. Brussels, COM (2016) 144 final, 4 March.

European Commission (2016f). Next Operational Steps in EU-Turkey Cooperation in the Field of Migration. Brussels, COM (2016) 166 final, 16 March.

European Commission (2016g). Communication on Establishing a New Partnership Framework with Third Countries under the European Agenda on Migration. Brussels, COM (2016) 385 final, 7 June.

European Commission (2018a). Migration and Home Affairs: Border Crossing, available at: https://ec.europa.eu/home-affairs/what-we-do/policies/borders-andvisas/border-crossing_en (accessed 20 June 2018).

European Commission (2018b). Migration and Home Affairs: Schengen Area, available at: https://ec.europa.eu/home-affairs/what-we-do/policies/borders-andvisas/schengen_en (accessed 20 June 2018).

European Council (2015a). Council Decision on Establishing Provisional Measures in the Area of International Protection for the Benefit of Italy and Greece. (EU)2015/1523, 15 September.

European Council (2015b). Integrity of the Schengen Area. 14300/15, 1 December. 
European Council (2016). European Council Meeting (18 and 19 February 2016)Conclusions. Brussels, 19 February.

European Parliament (2016a). Schengen Area: Update and State of Play. Briefing, March 2016.

European Parliament (2016b). The Cost of non-Schengen: Civil Liberties, Justice and Home Affairs Aspects, Study. September 2016.

European Parliament (2016c). At a Glance. What Think Tanks are Thinking. The Schengen Area. 15 February.

European Parliament and European Council (2006). Regulation (EC) No 562/ 2006 of the European Parliament and of the Council of 15 March 2006 Establishing a Community Code on the Rules Governing the Movement of Persons across Borders (Schengen Borders Code). 15 March.

Floyd, Rita (2018). 'Collective Securitisation in the EU: Normative Dimensions', West European Politics. doi:10.1080/01402382.2018.1510200

Gibney, Mathew J. (2004). The Ethics and Politics of Asylum: Liberal Democracy and the Response to Refugees. Cambridge, UK: Cambridge University Press.

Guild, Elspeth, Evelien Brouwer, Kees Groenendijk and Sergio Carrera (2015). 'What is Happening to the Schengen Borders?' Brussels: CEPS Papers in Liberty and Security, 86/December 2015.

Holehouse, Mathew (2015). 'Migrant Crisis: European Council President Tusk Warns Schengen on Brink of Collapse', The Telegraph, 13 November, available at: http://www.telegraph.co.uk/news/worldnews/europe/eu/11991098/Migrantcrisis-Donald-Tusk-warns-that-Schengen-is-on-brink-of-collapse-latest-news. html (accessed 20 June 2018).

Kahn, Mehreen (2016). 'The EU's €110bn Problem Slow Death of Schengen Risks', The Telegraph, 7 February, available at: http://www.telegraph.co.uk/ finance/economics/12143376/EUs-110bn-problem-save-Schengen-economiccrisis.html (accessed 20 June 2018).

Kirchner, Emil and James Sperling (2007). EU Security Governance. Manchester and New York: Manchester University Press.

Lazaridis, Gabriella and Khursheed Wadia (eds.) (2015). The Securitization of Migration in the EU. Debates since 9/11. Basingstoke: Palgrave Macmillan.

Macdonald, Terry (2015). 'Political Legitimacy in International Border Governance Institutions', European Journal of Political Theory, 14:4, 409-28.

Nielsen, Nikolaj (2016). 'Slovenia Threatens to Follow Austria with Border Checks', EUOberver, 18 January, available at: https://euobserver.com/migration/ 131886 (accessed 20 June 2018).

Nielsen, Nikolaj and Eszter Zalan (2016). 'Greece Risks Schengen Expulsion', EUObserver, 25 January, available at: https://euobserver.com/justice/131975 (accessed 20 June 2018).

Peers, Steve (2015). 'EU Law Analysis: Can Schengen be Suspended because of Greece? Should it be?', EU Law Analysis, 2 December.

Potyrała, Anna (2016). 'Poland Towards the Migration Crisis of 2015-2016', Przegląd Politologiczny, 2:2, 75-87.

Sperling, James and Mark Webber (2018). 'The European Union: Security Governance and Collective Securitization', West European Politics. doi:10.1080/ 01402382.2018 .1510193

Traynor, Ian (2016). 'Is the Schengen Dream of Europe Without Borders Becoming a Thing of the Past?', The Guardian, 5 January, available at: https:// 
www.theguardian.com/world/2016/jan/05/is-the-schengen-dream-of-europewithout-borders-becoming-a-thing-of-the-past (accessed 20 June 2018).

Waever, Ole (2015). 'The Theory Act: Responsibility and Exactitude as Seen from Securitization', International Relations, 29:1, 121-27.

Zalan, Eszter (2015). 'Greece Accepts EU Border Help under Schengen Threat', EUObserver, 4 December, available at: https://euobserver.com/migration/131387 (accessed 20 June 2018). 